\title{
The University Library - an Intercultural and Multicultural Space
}

\author{
Manuela Zănescu \\ Deputy Director ad interim \\ „Eugen Todoran” Central University Library of Timisoara \\ E-mail Manuela.Zanescu@bcut.ro
}

The 21st-century university library is a space hosting a multicultural education process, whether by design, with a clear strategy, or in an unstructured, yet natural manner. For that reason, my aim is to identify aspects of multiculturalism in the "Eugen Todoran" Central University Library of Timisoara (BCUT), using a descriptive presentation of each aspect, along with quantitative data analysis. In a multi-ethnic city, cultural and educational institutions carry that multi-ethnic, multicultural mark. We set out to monitor and analyse to what extent this phenomenon manifests itself in terms of collections, staff, services provided, users, as well as cultural programmes and European projects. For this study, we have chosen a descriptive method, with a quantitative one being used for the statistical data obtained from the library software or from the questionnaire addressed to our foreign users.

The BCUT's multicultural nature is visible in its collections, with books and magazines written in a variety of languages; in its staff belonging to various local ethnic groups; in its users, who are either members of local ethnic minorities or come from other countries; in its services, especially the ability to access documents in electronic format, the partnership projects, and the cultural events organized.

Keywords: university libraries; library collections; library staff; library users; cultural events; interculturality; multiculturality

\footnotetext{
"An organization that simply contains many different cultural groups is a plural organization, but it is considered to be multicultural if the organization values this diversity." (Du Mont, Buttlar and Caynon, 1994)
}

\section{Introduction}

Multiculturalism concerns the various cultures that coexist in a certain community space. „Multiculturalism is an answer to a series of specific problems concerning the coexistence of some populations viewed - or viewing themselves - as different." (Ferrol and Jucquois, 2005). It was defined in the 1960s starting from the situation of different ethnic communities living together in countries such as Australia or Canada. The concept was rooted in the need to protect the values and traditions of these people having multiple cultural identities (according to the definition from Encyclopaedia Britannica). At the same time, programmes were developed in the US providing for the implementation of multicultural education in the educational system. The report on the study carried out by a group of researchers led by James Coleman, Equality of Educational Opportunity, known as the Coleman Report, mentions the importance of information resources in intercultural education (Coleman et al., 1966). Another study discussing discrimination, racial segregation, and unlimited access to education is the Equal Educational Opportunities Act (EEOA), which became a US national law in 1974 and is regularly amended.

Multiculturalism is a defining feature of contemporary society as a result of people's mobility, as

Revista Română de Biblioteconomie şi Ştiința Informării = Romanian Journal of Library and Information Science ISSN 2559-5490, ISSN-L 1841-1940 • Volume 14 Issue 12018 pp. 1-10 https://doi.org/10.26660/rrbsi.2018.14.1.1

This work is licensed under a Creative Commons Attribution-NonCommercial-NoDerivatives 4.0 International License 
well as the uninterrupted migrant waves. The IFLA document entitled Multicultural Societies, Pluricultural People and the Project of Intercultural Education, developed by a team that included Romanians, mentions the development of intercultural skills by expanding the knowledge of, and access to, other cultures (Byram, 2009).

The areas richest in ethnic diversity are Banat, Transylvania, Bucovina, and Dobrogea. Thus, the country's western region has a long multicultural tradition. Tolerance is what governs the coexistence among the ethnicities in Timisoara. As this is a border area, the frequent economic or cultural contacts have shaped a liberal behaviour regarding the religion, culture, and traditions specific to all ethnic minorities. The city is characterized by plurilingualism, ethnically mixed families, and a multicultural landscape. There are theatres here in the languages of large minorities (German, Hungarian, plus a Serbian theatre currently being envisaged), schools where the teaching language is Hungarian, German or Serbian, faculties with foreign language sections, etc.

"The population of Banat is Romania's most diverse one in terms of culture, language, ethnicity, and religion. Thus, the Banat region is currently home to the following ethnic communities: Romanians, Hungarians, Germans, Serbians, Italians, Slovaks, Jews, Bulgarians, Russians, Ukrainians, Gypsies, Arabs, Persians, Indians, Chinese, Greeks, Africans, Asians, etc. Obviously, members of these groups also speak their corresponding mother tongue in addition to Romanian, as well as international languages such as: English, French, German, Italian, Spanish, Russian.” (Docea, 2010) [1]

As part of such a multicultural place, the university library could not but join this support of diversity and multiculturalism. Multicultural communication is present in all libraries, whether having a dedicated strategy or not.

The BCUT Managerial Strategy also takes into account aspects of cultural diversity:

"the increasing presence of foreign students (through the Erasmus programme, as well as through the West University's international openness strategy), is a compelling reason for 'adapting' the library, among other things, by purchasing specialized books in international languages and by providing public relation services in such languages." (Docea, 2010) [2]

Each university library is a multicultural oasis, thanks to the collections it owns, the services it provides, and the users it serves. Intercultural education at the library does not mean theorizing, but mainly interaction (with the librarians, the public, and the representatives of other cultures attending the cultural events).

\section{Multiculturalism in the collections}

Since its creation, the university library has owned document collections in foreign languages. Initially made up of donations from local personalities, the library, which was set up in 1948, did not contain sufficient documents for teaching and research as the Professor M. Ghermănescu mentioned in a letter addressed to the Public Ministry:

"We would like to mention that this Institute's teaching staff does not enjoy the same facilities as other colleagues in other university centres for their scientific work. The library has a very low supply of specialized books, purchased only occasionally, and not the most recent ones. " (Munteanu and Munteanu, 2004) [3]

As a result of the communist policy, the necessary content could only be purchased with a delay, and after much insistence with the Public Ministry, as can be seen from the notice sent to it by the Rector of the Pedagogical Institute (which subsequently became a university) at the time. Thus, in 
1951, the purchasing of magazines from abroad is approved. Most of them come from the USSR or from Communist Bloc countries.

Throughout the library's operation, since its creation up to the fall of the communist regime, the development of collections was influenced by the party's policy, which focused on maintaining uniformity in all libraries and was limited to exchanges with other communist countries. Books in Russian, German, Hungarian, and Serbian were purchased, especially through a service called "Libraries' Collection". They formed the majority of the library's foreign language book inventory. During the slight liberalization of the 1970s, books in English and French were also bought.

With the development of the inter-library exchange service, which started in 1967, the book collections and especially the magazine collections in foreign languages diversified. It was during that time that a range of periodical collections was created that has remained "intact" up to now, due to the language barrier - magazines in languages inaccessible to the library public: Albanian, Korean, and Chinese.

After 1990, the library started to receive, first enthusiastically, but then more and more reluctantly and discerningly, donations from the West. The entire content of the first boxes of foreign books was added to the collections, because it was filling a nearly 50-year-old void; however, the selection became increasingly rigorous among the following rounds of donations, taking into account the library profile and its space-related limits.

Until the late 2000s, the library regularly purchased both foreign books and magazines. Collections of magazines of academic interest from all over the world were thus built. Following the economic crisis of 2007, the number of subscriptions decreased, and in 2010, printed subscriptions were dropped, as their content was largely available in electronic databases.

The library's foreign book inventory changed between 1990 and 2017, with Russian, Hungarian, Serbian, and German books no longer being the most numerous. English-language books account for $35 \%$ of users' foreign book requests during the past years, followed by French $(22 \%)$ and German (16\%) books. Other foreign languages amount to less than $10 \%$ each, with Finnish, Hindi, and Norwegian ranking last. Of the total of 334,964 books in the database, 105,077 are in foreign languages. The breakdown of foreign-language books in the library collections looks like this: English - 36,957; French - 23,603; German - 18,979; Hungarian - 6,808; Russian - 730; Italian 2,658; Romany - 2,113; Latin - 1,437; Serbian-Croatian (Cyrillic) - 1,319; Spanish - 1,125.

The following foreign languages account for less than 50 titles each: Swedish - 29; Danish - 24; Finnish - 17; Hindi - 10; and Norwegian - 7. These figures reflect, first of all, the education structure at the West University. Most specializations with classes taught in foreign languages are in English, French, German or Spanish. The Faculty of Letters, Philosophy, and History has several specializations for English students, while the Faculty of Economics and Business Administration has specializations in English and French. The faculties of Political Science and Music \& Acting have one German section each.

The inclusion in the library database of the book collection housed by the German Cultural Centre in Timisoara and the collection belonging to the Portuguese Department of the Faculty of Letters, History, and Philosophy, the creation of the Banatica database consisting of 1,000 heritage books, of which 500 are part of the BCUT Special Collections Library and 500 are located in libraries in the Republic of Serbia, are signs of openness towards multiculturalism.

Another collection enriching the library assets is the Memorial Library. The documents it contains were donated to the library by the Third Europe Foundation. These materials of a memorial nature are included in the library database and contain: life-story interviews, journals, photographs, articles. The ethnicities represented in these documents are: Romanians - 150, Germans - 75, Roma - 3, Jews - 40, Serbians - 20, Hungarians - 20, Czechs - 2, Slovaks - 2, Italians - 3, Ukrainians - 5. 


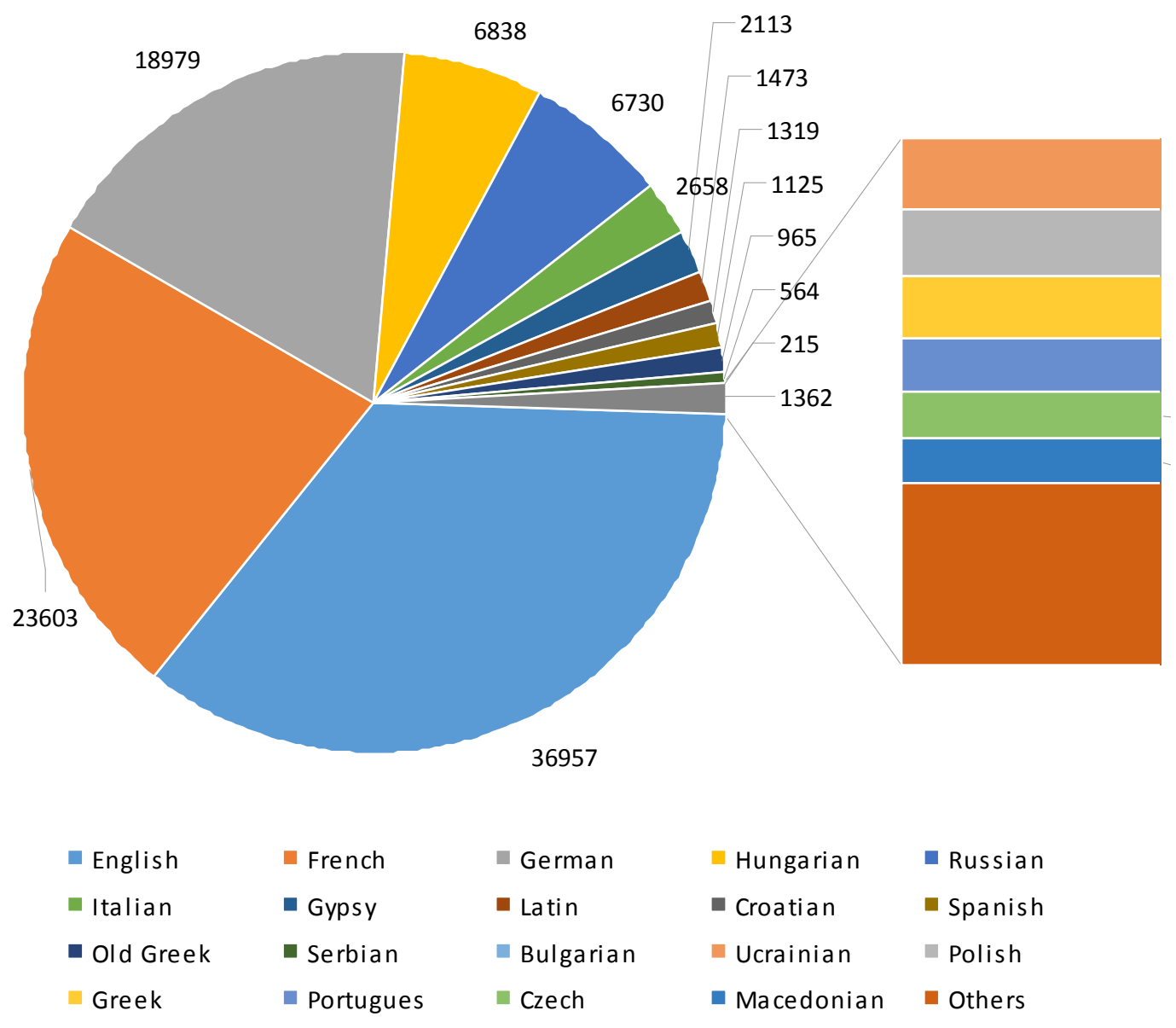

Fig. 1. Foreign-language books in the library collections

The setting-up of the various library collections implies impartiality and thus contributes to the public's multicultural education. To facilitate cultural diversity means also to develop multicultural collections, says Lois Buttlar, whose studies are concerning ethnic minorities and multicultural population in libraries (Buttlar, 1994).

\section{Multiculturalism among the staff}

In some cases, multiethnicity manifests itself among the staff. Roberto G. Trujillo and David C. Weber, in their study Academic Library Responses to Cultural Diversity: A Position Paper for the 1990s suggest hiring librarians belonging to ethnic minorities as a way to ensure a good level of engagement with, and service to, users (Trujillo and Weber, 1991). The BCUT staff have been ethnically diverse since the library's first years of operation. The library hired Serbian, Hungarian, and German ethnics even during the communist period.

A massive staff cut took place in the 1980s, which deeply affected the library's activity as the Serbian native Mr Trifu Cnezevici, library director during the 1980s, mentioned:

"With the staff thus reduced, we were only able to maintain minimal and precarious levels of new entry records and processing, as well as user service." (Munteanu and Munteanu, 2004) [4] 
The library currently employs Hungarian, Serbian, German, and Bulgarian ethnics. Of the total of 87 employees, 10 are of different ethnicities, accounting for $11 \%$ of the library staff. These are native speakers of Hungarian, German, Serbian, and Bulgarian, and some of them speak several foreign languages. Most of the other employees can provide information in English, French, German or Italian. The library included free English classes in the staff training programmes each year between 2011 and 2015, as well as a German course taught by a member of the institution's staff.

Since 1990, job applicants must take an elective foreign-language test as part of the application process. Thus, the staff involved in Collection Communication and Preservation can have conversations in English, for an efficient communication with library users from other countries.

Most of the staff have studied library science at BA level or as part of the postgraduate Library and Communication Science programme. The employees have received User Communication training, which has improved their work.

Librarians' tasks include presenting the library and holding user training sessions in English.

In order to identify the issues faced by employees of the Collection Communication service (who deal with library users from other countries), we organized a focus group attended by 10 librarians. The librarians mentioned that there are no problems in terms of communicating with users of other nationalities than the Romanian one and that such users often come to the library to study their own materials. There is good overall interaction with them, they are independent users who know their way around even better than Romanian students. The main issue identified following the discussions was connected with Arab students' requests for a private praying space. In her article Dealing with International Students in a Multicultural Era (1992), Sarcodie-Mensah mentioned that "Dealing with all patrons it is best for librarians to express religious and political views with extreme caution". Because librarians faced many different users with different needs is important to train them in dedicated sessions.

\section{Multiculturalism in the services}

For years, the international exchange service, started in 1961 in our library, was the only gate to the cultural world from all communist states. During the communist regime the exchange relations were restricted to universities from the communist countries. The service started to grow after the 1990 and now we have more partners. In 2017 the library received 226 items (among them there are 43 books and 84 de journals in foreign languages), from 36 de partners. Interlibrary loan is another way for the library to communicate with university libraries abroad.

In terms of services, multiculturalism manifests itself mainly after the 1990s, first of all in the development of the inter-library loan service, and then starting from 2000, when access to scientific literature was made easily available to users through electronic databases.

The first subscriptions to electronic resources were purchased at the end of the 1990s. Initially, students encountered some difficulty accessing these information resources, due to a lack of foreign language skills to enable them to understand the texts. As the requirements for being accepted at West University faculties grew more demanding, the students also became more interested in the scientific articles available on the academic platforms. Quite many of the library users now request remote access passwords. The diversity of the periodicals, books, and $\mathrm{PhD}$ theses indexed in the subscription databases has led to an increase in the number of the library's external users. Translating the library website into English was another step in opening towards foreign users.

It is technology that removes the barriers imposed by geographic and linguistic boundaries. Knowledge of a foreign language, especially English, makes it easy to communicate with anyone, from any corner of the world, in real time. 
Multicultural and multilingual library services ensure equality of service and access to information according to IFLA Manifesto (International Federation of Library Associations and Institutions, 2012) and it is of the 10 reasons to offer multicultural library services. We can find there a lot of examples of best practices of services targeted to undeserved groups, to minorities and to emigrants in order to use and improve our services.

In the era of technology, the library users can act independently, but they still need help from the specialised staff in order to easily find specific information.

\section{Multiculturalism among the users}

During the communist years, there were times when the West University enjoyed the presence of foreign lecturers and awarded scholarships for studies abroad, but very few students from outside Romania came to study here then. Most of the university's foreign students at the time were those in the preparatory year, taking Romanian language classes so they could then enrol at various faculties in the country, most often medicine. Most of the students learning Romanian came from Arab countries. Another category of foreign students during those times consisted of children of Romanians that had emigrated to the US or of German ethnics who had emigrated to Germany.

The opening towards the West in the 1990s led to the West University's participation in the Leonardo and Erasmus programmes, faculty department partnerships, and student and administrative staff exchanges. Thanks to this opening, the number of BCUT foreign users has also gone up during the past years.

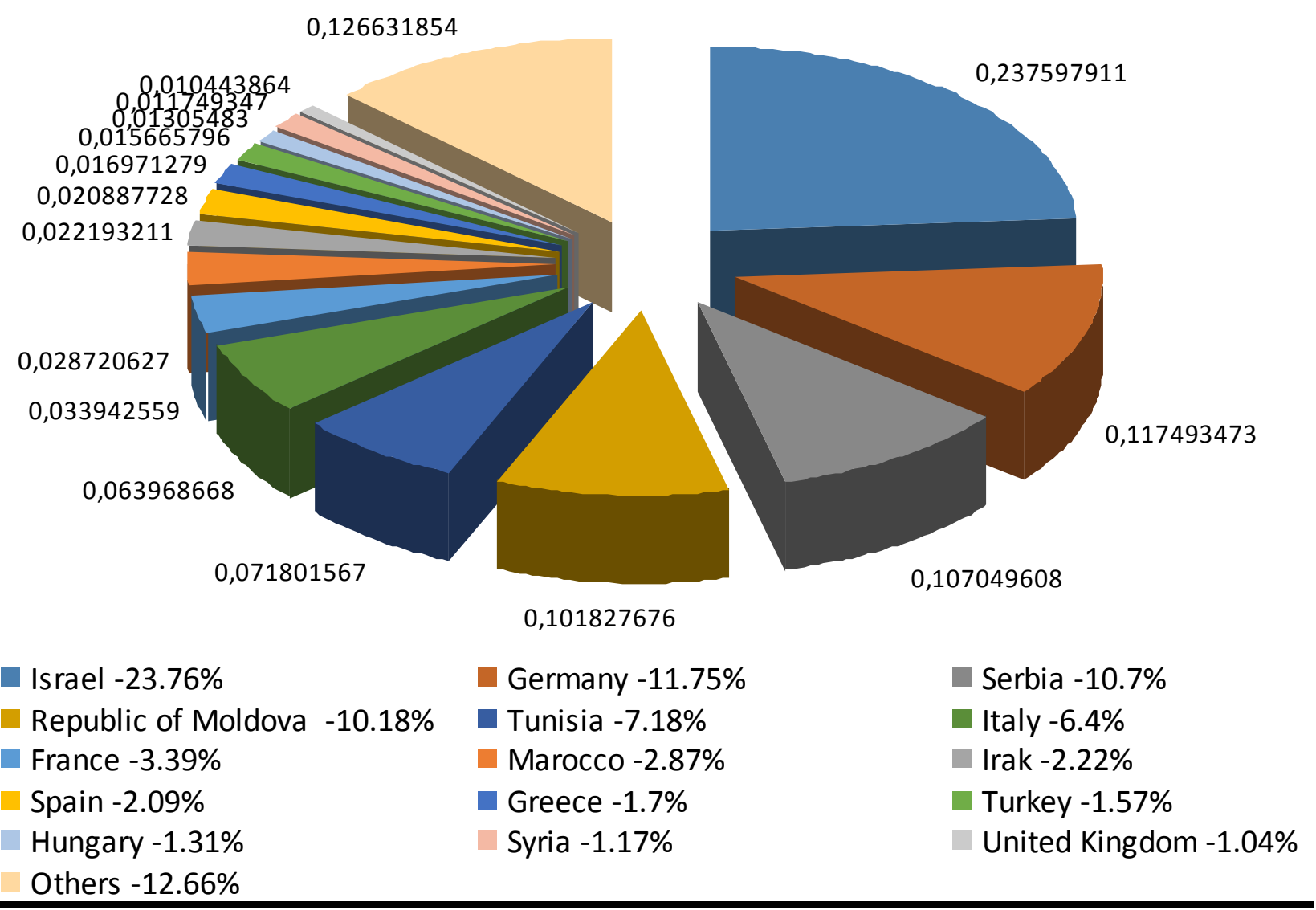

Fig. 2. Foreign user percentages and countries of origin

Most respondents to the questionnaire focusing on the library's foreign student users mentioned using the reading rooms occasionally, usually during the examination period. $81.8 \%$ of foreign students use the library for study and only $10 \%$ of them borrow books or access the databases. 
This explains why $54.5 \%$ of them gave a neutral response to whether the collections suit their information needs, while $36.5 \%$ of them regard the collections as being suitable. Most of them view the librarians as being professional, mindful of the users' information needs ( $80 \%)$, while the others are of a neutral opinion. Only $46 \%$ of respondents say they ask librarians for help. They are satisfied by the space made available and by the library opening hours. $18 \%$ of them mention the unsatisfactory performance of the library Wi-Fi network.

Intercultural dialogue is now made easy thanks to the educational system training and introducing students to other cultures. Foreign language classes in school curricula also include lessons in culture and civilization, and plurilingualism is now common in society.

In the multicultural environment of university libraries, students of various ethnicities and from various countries have a chance to learn both the differences and the similarities. Through the meetings occasioned by using the reading rooms and participating in the cultural events taking place in the library building, students not only get to know other cultures, but also have a chance to interact and resonate. This happens with all users studying within the library spaces. Mixed groups of Romanian and foreign students or students from different countries are a common sight at the library.

Recognizing the similarities and differences between users can lead to the provision of new services to all of them, regardless of their origin. Another way of harnessing this information can lead to better staff training, through training sessions and workshops to facilitate communication with a multicultural public.

\section{Multiculturalism in the library's relations}

The library's partnerships involve national and international exchanges, national and international loans, cooperation protocols with various institutions whose employees wish to become library members, and partnership agreements or projects with cultural institutes or consulates for the organization of cultural events.

The projects carried out as partnerships have facilitated both the development of the database and the professional development of the staff, thanks to their being involved in the project activities. The first partnership agreement was concluded in 2012 for the setting up of the European Documentation Centre following an application with the European Commission in Bucharest. This centre aims to provide complex information and documentation services, giving its beneficiaries access to a collection of documents on European topics, developed both by Community institutions and by other publication providers, in traditional or electronic format, as well as online; to promote and develop education and research in the field of European integration by organizing events such as presentations, conferences, workshops. The librarians attending to users of this European Information and Documentation Centre provide general information on EU policies, promote and provide data concerning EU institutions and the Union's areas of activity, and guide users to find any kind of information on this topic.

Another step towards multiculturalism at the BCUT is the Romania-Serbia cross-border project called Library as an Instrument of Building Regional Identity and Strengthening Social Cohesion BIBLIO-IDENT, carried out as part of the Romania-Serbia IPA Cross-Border Cooperation Programme.

The BCUT's partner in this project was the Zarko Zrenjanin Public City Library. The cooperation between the two institutions aimed to strengthen social and economic cohesion through information exchange, to stimulate scientific research into the joint history of the two border regions belonging to the historic Banat, and to create a joint database of heritage books. Project goals included: promoting cultural diversity; promoting cultural and good neighbourhood exchanges; respect for cultural diversity; showcasing and highlighting the heritage book inventory, 
from the historic Banat up to 1900; building the Banatica database of heritage books dealing with the historic Banat or written by authors from this region.

The project activities, carried out with the participation of over 500 people from both countries, consisted in: 4 thematic regional and international conferences held in Timisoara, on the history of the Banat Region; 2 workshops attended by librarians from Romania and Serbia to acquire advanced heritage book description skills; building a joint heritage book database, The Banatica Archives (scanning, indexing, and translating the title page and table of contents of the 500 selected books into 4 languages - English, Serbian, Hungarian, and German), as well as scanning the entire content of 100 books.

Of the project conferences, I would like to mention Interculturalism in Banat. Social Heritage and Identity Reconstruction - a regional conference, and Regional Identity and Social Cohesion. The Role of Libraries in Building Regional Identity and Social Cohesion - an international conference with the participation of our partners from Serbia, as well as specialists in anthropology and history.

Social cohesion is a consequence of a multicultural social life and manifests itself through joint cultural programmes by neighbouring countries and a permanent cultural dialogue. Opening towards the regions is an act of promoting culture by showing the cultural diversity it contains.

Another cooperation between the library and cultural partners from abroad was the grant obtained for the study visit to Norway. The "Eugen Todoran" Central University Library was the beneficiary of a Norway Grants-funded project to establish cooperation relations with the Østfold University Library. For this purpose, two librarians from our institution went to Oslo and Halden in September 2015. The project goals included establishing a partnership relationship with the Østfold University Library in order to carry out a joint project and facilitating an exchange in the following fields: digitizing old library documents belonging to the national cultural heritage and designing a guidance/education programme for the library users, suitable to their cultural specificity, supporting professional development, and facilitating cooperation in order to adapt the library space to users with disabilities.

Following this visit, in May 2016, four librarians from the Østfold University Library were invited by our library to hold a workshop in the library auditorium and made a presentation of digital tools for BCUT librarians.

These projects helped establish cultural relations that have led to mutual cultural enrichment.

\section{Multiculturalism through the cultural programmes}

The cultural event programmes are an intercultural dialogue initiated by the library with its users. In time, this dialogue has involved major national and foreign cultural actors. The cultural events are held on a monthly basis and aim to earn public loyalty and educate the public through their academic and cultural content. We have aimed to organize academic events, inviting personalities from various fields, of interest both to researchers and to teachers, students, and the general public interested in various science and art topics. The cultural activity calendars include book launches and debates, conferences, narrative films and documentaries, musical and theatrical performances, exhibitions, workshops on library science and information science.

From the long list of cultural meetings, we are going to select just those moments that were accomplished with the involvement of foreign partners or the participation of guests from other countries. Since 2011, our event format has included the organization of events that show parts of other peoples' culture to the public. We started with the National Day of the Republic of Serbia, in January, 2011, aiming to present to the public the image of a great Enlightenment figure - the writer and translator Dositej Dimitrije Obradović, born in Ciacova, Timiș County.

In May 2011, the Mexican Culture Days introduced event participants to the defining features of Mexican culture: Mr Rodolfo Arturo Herrera Saldaña, Cultural Affairs Officer at the Mexican Embassy in Bucharest, held a presentation (in Romanian) entitled Introduction to Mexican Culture; a 
reading of Mexican poetry, translated and read by students at the Faculty of Letters at the West University of Timisoara; a round table (in Spanish): Cultural Identities in Mexico and Spain (with the participation of Mr Rodolfo Arturo Herrera Saldaña, Cultural Affairs Officer at the Mexican Embassy in Bucharest, as well as Jorge Gonzáles Garrido, a teacher at J.L. Calderon High School in Timisoara, AECI Lecturer Sonia Sobral Vázquez, and Mr José Miguel Viñals - now Honorary Consul of Spain in Timisoara); Mexican short films (Guardians of Silence, Mexican Golden Hands, México à la carte, The Offering of Souls). The two Mexican culture days ended with a traditional Mexican dance prepared by the three Mexican citizens who were in Timisoara at that time.

Some of these actions that facilitate intercultural dialogue have become permanent by now: the German Culture Days and the Polish Film Days are known to a wider public in Timisoara, not just to university students. The appreciation these events have enjoyed has led the local media to enquire and ask for details of their content at each new edition. The cooperation with the consulates in the city is a good tradition of our institution.

The step taken by the library towards the cultural centres and consulates through constant cooperation is a form of cultural dialogue. The interest in other cultures and the availability of interaction with representatives of these institutions in order to bring to the library's audience cultural events representative of other cultures show not just our staff's intercultural skills, but also our library's multicultural nature. Another way to extend this subject is to continue the research about the multiculturality and interculturality in cultural activities, through surveys and interviews to finding out more about the public's expectations and preferences. Cultural services can serve as examples of intercultural education when designed and organized that way. This type of interaction involves socializing and cultural immersion. The library thus becomes a place of intercultural exchanges, encouraging and fostering open expression, tolerance, and mutual respect.

\section{Conclusions}

"The communication between the Minorities in Banat has always been remarkable, its support being plurilingualism practiced in all minority ethnic communities" (Banciu and Coardos, 2012) [5]. That background made the university library an open space for all users, and help us to very easy identify multiculturality in each aspect of its existence. In a short description we can see that the library develops culturally diverse and multilingual collections and services, including electronic resources.

The paths that open up a constant preoccupation of the library for multiculturalism and interculturality are various. From the appropriate completion of collections to the development of cultural competences among employees, the organization of cultural programs, the initiation of projects and the implementation of new services for users.

Pointing out all the ways in which multiculturality is noticeably in our library was necessary as it is the first contribution that helps defining ourselves as an organization which has a global reach with a local touch. The lack of prior research on this topic determined me to give this general view on the subject with only a few highlights on the forms of multiculturality. There are many possible new or expanded ways of in-depth interpretation and ways of studying multi-and inter-cultural issues in our library.

The key finding in my analysis is the diversity of approaches to the subject. A comparative method of research can reveal, for example, the evolution of the users' interest in resources in other languages. An increased cooperation between the Library and the University on the issues of multi/ interculturalism and more information sharing among the two would certainly lead to new approaches to the subject.

By being aware of all the facets of multiculturalism, the library discovers its own cultural identity, its cultural diversity and pluralism. 


\section{Notes}

1. Romanian version: „Populaţia Banatului se caracterizează prin cea mai mare diversitate culturală, lingvistică, naţională şi confesională la nivelul României. Astfel în prezent există în regiunea Banatului următoarele comunităţi naţionale: români, maghiari, germani, sârbi, italieni, slovaci, evrei, bulgari, ruşi, ucraineni, țigani, arabi, persani, indieni, chinezi, greci, africani, asiatici etc.. Evident, membrii acestor grupuri vorbesc pe lângă română şi limbile materne aferente, dar şi limbi de circulaţie internaţională ca: engleza, franceza, germana, italiana, spaniola, rusa".

2. Romanian version: ,prezenţa în continuă creştere a studenţilor străini (prin programul „Erasmus”, dar şi prin strategia Universităţii de Vest de deschidere internaţională), obligă la măsuri de „adaptare” a bibliotecii, între altele prin achiziţionarea de cărţi de specialitate în limbi de circulaţie internaţională şi prin servicii de relaţii cu publicul în astfel de limbi”".

3. Romanian version: „Tinem să precizăm că membrii corpului didactic al acestui Institut nu au înlesnirile celorlalţi colegi din alte centre universitare în vederea muncii lor ştiinţifice. Biblioteca este foarte puţin înzestrată cu cărţi de specialitate, procurate ocazional şi nu dintre cele mai noi".

4. Romanian version: „Cu personalul astfel redus nu am reuşit decât să menţinem la o limită minimă şi precară atât evidenţa şi prelucrarea publicaţiilor nou-intrate, cât şi servirea beneficiarilor noştri. În aceste condiţi nu se putea efectua nici una din lucrările rămase restante şi nici o programare nu ar fi putut fi respectată".

5. Romanian version: „Comunicarea între minorităţile din Banat a fost întotdeauna remarcabilă, suportul său fiind plurilingvismul practicat în toate comunităţile etnice minoritare”.

\section{References}

Banciu, D. and Coardoş, D. (2012) Promovarea multiculturalităţii în era digitală în spiritul dezvoltării durabile [Promoting multiculturalism in the digital age in the spirit of sustainable development], Revista Română de Informatică şi Automatică, 22(2), pp. 39-48, available: https://rria.ici.ro/wp-content/ uploads/2012/06/06-art.-DB-Multiculturalitate-1.pdf [accessed 11.04.2018].

Buttlar, L. (1994) Facilitating cultural diversity in college and university libraries, The Journal of Academic Librarianship Online, 20(1), pp. 10-14, available: https://doi.org/10.1016/0099-1333(94)90128-7 [accessed 11.04.2018].

Byram, M. (2009) Multicultural Societies, Pluricultural People and the Project of Intercultural Education, Strasbourg: Council of Europe Language Policy Division, available: https://rm.coe.int/multiculturalsocieties-pluricultural-people-and-the-project-of-interc/16805a223c [accessed 10.03.2018].

Coleman, J.S. et al. (1966) Equality of educational opportunity, Washington: National Center for Educational Statistics, available: https://files.eric.ed.gov/fulltext/ED012275.pdf [accessed 11.04.2018].

Docea, V. (2010) Strategia managerială [Managerial Strategy], available: http://www.bcut.ro/dyn doc/ StratManag.pdf, pp.2-3 [accessed 11.04.2018].

Du Mont, R.R., Buttlar, L. and Caynon, W. (1994) Multiculturalism in libraries, Westport: Greenwood Press, p. 18.

Ferrol, G. and Jucquois, G. (eds.) (2005) Dicționarul alterității şi al relatiilor interculturale [Dictionary of alterity and intercultural relations], Iaşi: Polirom, p. 451.

International Federation of Library Associations and Institutions (2012) IFLA/UNESCO Multicultural Library Manifesto - Implementation Kit, [s.1.]:[s.n.], available: https://www.ifla.org/files/assets/libraryservices-to-multicultural-populations/publications/ifla-unesco-multicultural-1ibrarymanifesto_implementation-kit_2012-12.pdf [accessed 11.04.2018].

Multiculturalism, Encyclopedia Britannica, available: www.britannica.com/topic/multiculturalism [accessed 11.04.2018].

Munteanu, I. and Munteanu, R. (2004) Universitatea de Vest din Timişoara [West University of Timisoara], Timişoara: Editura Universităţii de Vest, p. 80.

Sarkodie-Mensah, K. (1992) Dealing with International Students in a Multicultural Era, Journal of Academic Librarianship Online, 18(4), pp. 214 -216, available: https://eric.ed.gov/?id=EJ451951 [accessed 11.04.2018].

Trujillo, R.G. and Weber, D.C. (1991) Academic Library Responses to Cultural Diversity: A Position Paper for the 1990s, Journal of Academic Librarianship, 17(3), pp. 157-161, available: http:// search.ebscohost.com/login.aspx?direct $=$ true $\& \mathrm{db}=$ bth $\& A N=9705180885 \&$ site=ehost-live $\quad$ [accessed 11.04.2018]. 